\title{
A wooded riparian strip set up for nitrogen removal can affect the water flux microbial composition
}

\author{
Mizanur Md. Rahman, ${ }^{1,2}$ Marina Basaglia, ${ }^{2}$ Lorenzo Favaro, ${ }^{2}$ Bruno Boz, ${ }^{2}$ Bruna Gumiero, ${ }^{3}$ \\ Sergio Casella ${ }^{2}$ \\ ${ }^{1}$ Department of Biotechnology and Genetic Engineering, Islamic University, Bangladesh; \\ ${ }^{2}$ Department of Agronomy Food Natural resources Animals and Environment, University \\ of Padova, Legnaro (PD), Italy; ${ }^{3}$ Department of Evolutionary and Experimental Biology, \\ Bologna University, Bologna, Italy
}

\begin{abstract}
This research is part of a project aimed at verifying the potential of a specifically assessed wooded riparian zone in removing excess of combined nitrogen from the Zero river flow for the reduction of nutrient input into Venice Lagoon. Specific objectives were pursued to determine seasonal fluctuations of the microbial populations from the input water to a drainage ditch, conveying back the flux into the river after passing through the soil of the wooded riparian strip. The bacterial communities were determined by combined approaches involving cultivation, microscopic methods and DNA based techniques to determine both culturable and total microbial community in water. The results indicate that the size of the bacterial population, including the culturable fraction, increases from the river to the drainage ditch especially on the warm season. The multiple approach here adopted enabled also to demonstrate that the special condition created in the buffer strip supports the development and the metabolism of the microbial community. The nature of the bacterial population, in terms
\end{abstract}

Correspondence: Sergio Casella, Department of Agronomy Food Natural resources Animals and Environment, University of Padova, Agripolis, viale dell'Università 16, 35020 Legnaro (PD), Italy.

E-mail: sergio.casella@unipd.it

Key words: microbial diversity, nitrogen removal, riparian strip, water fluxes, $16 \mathrm{~S}$ rDNA sequence, denaturing gradient gel electrophoresis.

Acknowledgments: this work was supported by Consorzio di Bonifica Acque Risorgive, Regione Veneto and Veneto Agricoltura. We thank the Environmental Protection Agency of the Veneto Region (ARPAV) for water analysis. M. Md R. was recipient of a PhD fellowship of the University of Padova. L.F. is recipient of Assegno di ricerca Senior grant from the University of Padova.

Conference presentation: AISSA, Palermo, 2012.

Received for publication: 10 July 2013.

Revision received: 24 January 2014.

Accepted for publication: 24 January 2014.

(C) Copyright M.Md. Rahman et al., 2014

Licensee PAGEPress, Italy

Italian Journal of Agronomy 2014; 9:548

doi:10.4081/ija.2014.548

This article is distributed under the terms of the Creative Commons Attribution Noncommercial License (by-nc 3.0) which permits any noncommercial use, distribution, and reproduction in any medium, provided the original author(s) and source are credited. of phylotypes distribution, was investigated by $16 \mathrm{~S}$ rDNA analysis indicating that the most represented genera belong to Gamma-proteobacteria, which is known to include an exceeding number of important pathogens. In spring, the effect of the buffer strip seems to significantly reduce such a sub-population. The changes observed for the total bacterial community composition become much evident in summer, as revealed by both denaturing gradient gel electrophoresis cluster analysis and by the diversity index calculation.

The hydraulic management coupled to the suspension of farming practices and the development of the woody and herbaceous vegetation resulted in a condition suitable for the containment of undesired microbiota (mainly during the spring season) while continuing to support denitrification activity (especially throughout the summer) as verified by the total nitrogen removal.

\section{Introduction}

Bacteria are recognized as important agents in biogeochemical processes in all aquatic ecosystems. It is well known that heterotrophic prokaryotes play relevant roles in the structure and dynamics of trophic web networks and in the re-mineralization of organic matter (Azam and Long, 2001). Surveys have already been performed in many marine environments, including oligotrophic open ocean (Fuhrman et al., 1993), coastal temperate (Kelly and Chistoserdov, 2001; Acinas et al., 1999) and marine sediments (Bowman et al., 2003; Heijs et al., 2008). Most of the above cited studies helped to improve our understanding of spatial distributions (Sala et al., 2008; Vieira et al., 2008), the overall understanding of the global patterns of aquatic bacterial diversity (Pommier et al., 2007) and even helped to comprehend local and global biogeochemical processes (Zehr and Ward, 2002; DeLong and Karl, 2005).

The wooded riparian strips or buffer strips consist of wooded areas interposed between terrestrial and aquatic ecosystems. They play an important role in the regulation of nutrient dynamics and in particular in nitrogen removal. The nitrogen cycle strongly depends upon microbial activities and it is important to note that combined nitrogen is considered one of the most important limiting factors for plant growth. Although nitrogen fixation can be considered as a positive activity for the whole ecosystem, denitrification may play a double role in relation to the context it takes place: while nitrogen removal from a $\mathrm{NO}_{3}{ }^{-}$fertilized soil is an absolute detrimental process, the gasification of nitrate from surface and subsurface water flows of terrestrial and aquatic ecosystems may result a very useful tool for reducing nitrate and nitrite pollution (Knowles, 1982; Gumiero et al., 2011).

The most important factor to be investigated is the site hydrology which regulates the sequence of anoxic and aerobic conditions togeth- 
er with nitrate input to the system, thus also affecting the distribution of bacterial communities in the riparian strip (Rahman et al., 2014; Boz et al., 2013). Our understanding of microbial diversity in aquatic environments is still limited due to the highly variable physical and biogeochemical conditions.

This study is part of a project aimed at verifying the potential of a specifically assessed wooded riparian zone in removing excess of combined nitrogen from the Zero river flow for the reduction of nutrient input into Venice Lagoon. Specific objective of the present work was to investigate on seasonal fluctuations of the microbial populations from the input water to a drainage ditch, conveying back the flux into the river after passing through the soil of the wooded riparian strip. The bacterial communities were determined by combined approaches involving cultivation, microscopic methods and DNA based techniques to determine diversity of both culturable and total microbial populations in water.

\section{Materials and methods}

\section{The experimental site and sample collection}

The experimental site, located $15 \mathrm{~km}$ from Venice, Italy, has been deeply described in Gumiero et al. (2011). The experimental design was planned according to the NICOLAS project (EC DGXII, 1997-2000 ENV4-CT97-0395) to examine a three-zone buffer system.

The particular structure of the experimental field, which is characterized by ridges and furrows, facilitates surface and sub-surface flows of water through the woodland strips. The water drains through the field from the irrigation ditch (located on a small ridge) towards the parallel network of drainage ditches as described in details in Gumiero et al. (2011).

Water samples were collected on March (M), April (A) and July (J) from three different sites: the river (R), the irrigation ditch or Input water (I) and the output water of the drainage ditch (0). All the samples were collected and analysed in triplicate.

For 5-cyano-2,3-di-4-tolyl-tetrazolium chloride (CTC) assay, direct viable count, and plate count analysis, tenfold water serial dilutions were prepared as described by Toffanin et al. (2000).

\section{Water chemical parameters}

Water samples were filtered through a $0.45 \mu \mathrm{m}$ polyvinylidene fluoride filter (Merck Millipore) and analysed within 24-36 h for dissolved total nitrogen by the persulphate oxidation method (Valderrama, 1981). Principal component analysis (PCA) was performed by the XLSTAT 2007 software to determine the possible relationships among the two seasons and the three sites of sampling in terms of nitrogen $(\mathrm{N})$ removal $\left(\mathrm{mg} \mathrm{mL}^{-1}\right)$.

\section{Microscope-based analyses}

CTC reduction assay was performed using the procedure described in Basaglia et al. (2007): in short, aliquots of water serial dilution (1:10) were incubated with $4 \mathrm{mM} \mathrm{CTC}$ in phosphate buffer solution and after $2 \mathrm{~h}$ staining, filtered through a $0.2 \mathrm{~m}$ pore size black polycarbonate membrane filter (Merck Millipore, Billerica, MA, USA). Filters were air dried and mounted with a low-fluorescence immersion oil (Molecular Probes Inc., Eugene, OR, USA) on glass microscope slides.

Viable bacteria were tested using the Live/Dead BacLight bacterial viability kit (Molecular Probes) following the instruction of the manufacturer; after $15 \mathrm{~min}$ of incubation, the samples were filtered through a 0.2 -mm black polycarbonate filter (Millipore), and the filter mounted as described above.
CTC-reduction and viability were observed by fluorescence microscopy (Olympus fluorescent microscope BX60) equipped with a blue 420-nm exciter filter (Olympus BP 490). At least 20 fields or 300 cells were recorded for each sample.

\section{Culturable microorganisms}

Culturable bacteria in water samples were evaluated as described by Rahman et al. (2014): $0.1 \mathrm{~mL}$ aliquots of water serial dilution (1:10) were dropped and spread onto the solid media plate count agar. Petridishes were incubated aerobically at $30^{\circ} \mathrm{C}$. After 14 days the number and the morphology (shape, size, colour, etc.) of colonies were recorded. Representative colonies of different morphologies were isolated and stored in glycerol at $-20^{\circ}$ for molecular analyses.

\section{DNA extraction from isolated colonies}

DNA was extracted from single colony by alkaline lysis: one colony was suspended in an Eppendorf tube with $50 \mu \mathrm{L}$ of lysis buffer $(2.5 \mathrm{~mL}$ $10 \%$ sodium dodecyl sulfate, $5 \mathrm{~mL} 1 \mathrm{M} \mathrm{NaOH}, 92.5 \mathrm{~mL}$ MilliQ water). After 15 min the suspension was heated at $95^{\circ} \mathrm{C}$, then the tube was centrifuged for $5 \mathrm{~min}$ at $13,000 \mathrm{xg}$, the supernatant was transferred to a new tube and $90 \mu \mathrm{L}$ MilliQ water was added. Extracted DNA was stored at $-20^{\circ} \mathrm{C}$ for further molecular analyses.

\section{Amplification and sequencing of 16S rDNA from culturable bacteria and diversity index}

16S rDNA amplification by polymerase chain reaction (PCR) and sequencing was performed as described in Rahman et al. (2014). The amplified DNA was visualized by gel electrophoresis and sequenced. The most similar bacterial species were found in the GenBank by using BLAST (Basic Local Alignment Search Tool) search (http://www.ncbi. nlm.nih.gov).

Diversity was measured by Shannon diversity index (H) (Shannon and Weaver, 1963; Kapley et al., 2007; Ibekwe et al., 2010).

\section{Total DNA extraction directly from water}

Two hundred fifty mL water was filtered through polyethersulfone filters $(0.2 \mu \mathrm{m}$ pore size; Pall Corp., Port Washington, NY, USA). One filter and a half was used to extract DNA using the Power Soil TM DNA Isolation Kit (Mo Bio Laboratories Inc., Carlsbad, CA, USA). DNA isolation was performed according to the manufacturers' instructions, modified as follows: extra glass beads $(0.15-0.30 \mathrm{~g}$, bead size $0.1 \mathrm{~mm})$ were added to the half filter and the cells were disrupted by bead beating (mini-bead beater ${ }^{\mathrm{TM}}$; BioSpec products, Bartlesville, OK, USA). Final purification of the extracted DNA was performed using the Wizard® DNA clean-up system (Promega, Madison, WI, USA). This purified DNA was used for PCR Amplification of 16S rDNA as described above.

\section{Denaturing gradient gel electrophoresis analysis of polymerase chain reaction-amplified 16S rDNA from total DNA and diversity index of denaturing gradient gel electrophoresis banding pattern}

Denaturing gradient gel electrophoresis (DGGE) analysis of PCRamplified 16S rDNA fragments was conducted as described in Rahman et al. (2014). At least two different DGGE runs were carried out for all samples and for both loading orders of the samples on gel, in order to estimate the reproducibility of DGGE profiles generated with different loading schemes of samples.

DGGE bands were identified by visually inspecting gel images in BioNumerics version 4.5 software program through band intensity. Brightness and contrast were adjusted for each image to facilitate band 
identification. Similarities between microbial communities of DGGE profiles generated by Dice similarity index were based on UPGAMA (Unweighted Pair Group Method using Arithmetic Averages) analysis using the BioNumerics version 4.5 software (http://www.appliedmaths.com). Diversity was measured by Shannon diversity index $(\mathrm{H})$ as described above.

\section{Results}

Viable (living) cells, metabolically active (5-cyano-2,3di-4-tolyl-tetrazolium chloride) cells and culturable bacteria

Viable, metabolically active cells and culturable bacteria were determined in water samples collected in different seasons from the river, the input (irrigation ditch) and the output (drainage ditch) water. Figure 1 indicates that the number of living bacteria is increasing toward the hot season. However, while in March the size of the bacterial population seems to moderately increase, in July it gains more than one order of magnitude in the output water. CTC analysis, indicating respiration ability of bacteria, shows that also the metabolically active fraction of the population follows similar trends, suggesting that, especially in summer, the conditions in the buffer strip support the development and the metabolism of the bacterial populations. This is confirmed by the observation that the culturable bacteria (CFU) are also increasing, and in July a difference of two logs was found between the river and the output water.

\section{Phylotypes distribution and 16S rDNA sequence analysis of water culturable community}

Phylogeny of 16S rDNA sequences of several hundreds culturable isolates, performed during the different seasons, resulted in a number of different genera most of which belonging to Gamma-proteobacteria and the others distributed among six major bacterial lineages, namely Firmicutes, Actinobacteria, Alpha-proteobacteria, Beta-proteobacteria and Flavobacteria, with smaller groups within Sphingobacteria and some unclassified (Figure 2). The abundance of Gamma-proteobacteria (almost $60 \%$ of the total isolates in March) may represent a concern as this group include an exceeding number of important pathogens, both for humans and plants. In effect, the most represented genera, as revealed by the $16 \mathrm{~S}$ rDNA sequencing, were found to be Pseudomonas (36\%), Pantoea (12\%) and Aeromonas (7\%), with other minor percentages of Citrobacter, Xanthomonas and Acinetobacter. The meaning of this finding has to be connected to the water flux of the river that collects the water from a wide range of different sites such as urban settlements, livestock farms and agricultural soils. Leaving aside the effectiveness of the buffer strip to remediate $\mathrm{N}$ content of the water flux, with nitrate removal efficiency reaching $70 \%\left(36.722 \mathrm{~kg} \mathrm{ha}^{-1}\right.$ month ${ }^{-1}$ of $\mathrm{N}^{-\mathrm{NO}_{3}}$ ) (Rahman et al, 2014), the effect of the wooded riparian strip soil seems to be also interesting in abating the percentage of bacterial populations known to be potentially dangerous.

\section{Denaturing gradient gel electrophoresis analysis of} the microbial communities in water at different sea-

\section{sons and sites}

In order to get information on the composition of the total bacterial community of water, and not only on the culturable portion of the bacterial population, total DNA was extracted from the water samples and the amplicons of the variable region V6-V8 of $16 \mathrm{~S}$ rDNA were analysed by DGGE. An example of the dendrograms obtained is reported in

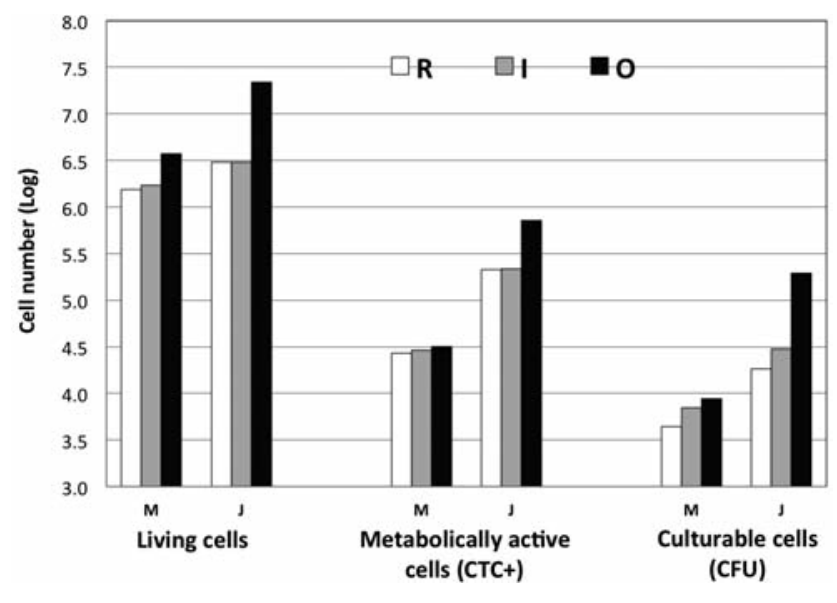

Figure 1. Viable (living) cells, metabolically active (CTC+) cells and culturable (CFU) bacteria collected in two different periods (M: March and J: July) from the river, the input and the output water. The data, expressed as the $\log (10)$ of the cell number, represent the mean of the values obtained from three analogue samples, and standard deviations are always below $5 \%$.
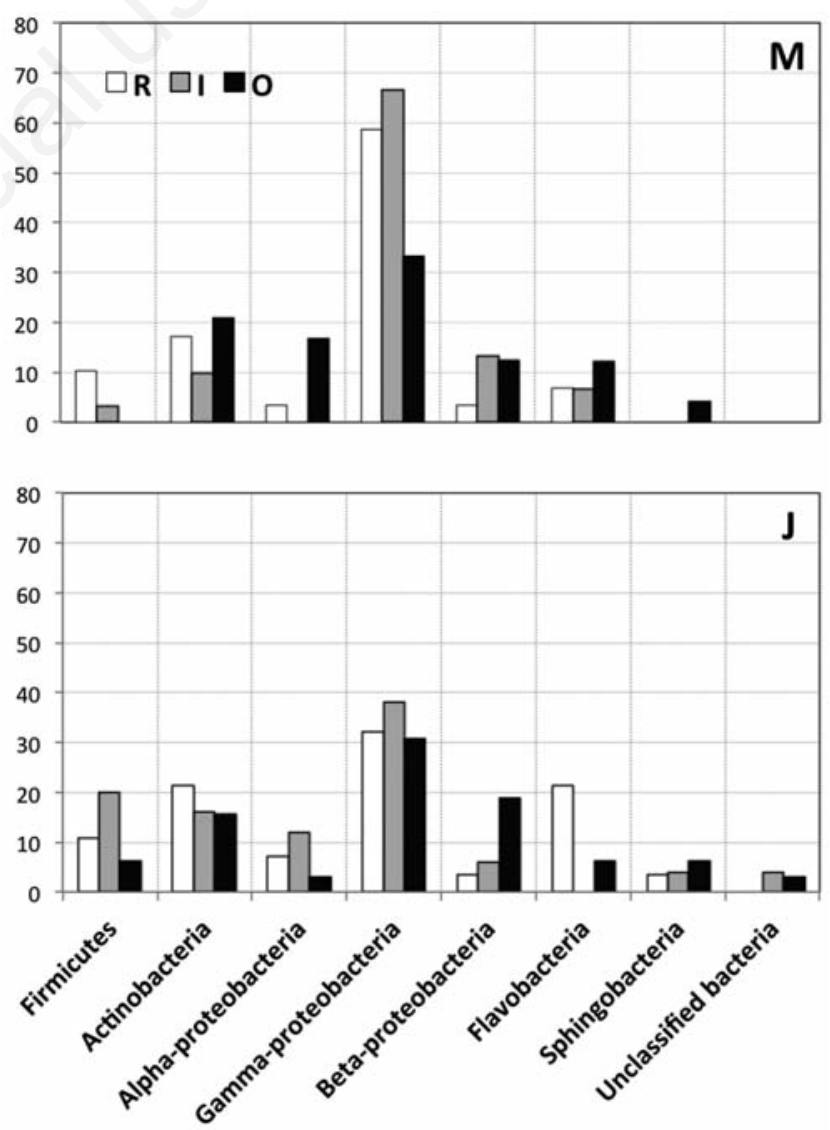

Figure 2. Phylotypes distribution of culturable bacteria as obtained by $16 S$ rDNA sequence in March $(M)$ and July (J). Samples were collected directly from the river (R), from the irrigation ditch (I) and from the output water of the drainage ditch (O). The data are reported as percentage on the total number of isolates. 
Figure 3. As already observed for the culturable fraction of the bacterial population, in July the samples resulted clearly different as compared to those of the spring season (March and April) that, in turn, did not significantly differ each other. However, for each season, the profiles related to the place of sampling do clusterise separately, thus confirming the effect of the buffer strip in modifying the bacterial population of the flowing water. Particularly, the bacterial populations of July resulted in a highly different profile (more than 70\% dissimilarity value), with the output water falling in a clearly separate cluster.

Shannon diversity index $(\mathrm{H})$ was determined for the river, irrigation ditches and drainage ditches water in March, April and July for both culturable and total bacterial fraction. Since between March and April no significant differences were observed, Table 1 reports the data related only to March and July. The values indicate an increase in bacterial diversity for the drainage ditches as compared to the irrigation ditches and the river, for both the seasons, either for the culturable bacterial fraction and the total bacterial community.

In order to link the above observations to the real efficiency of the buffer strip, PCA analysis was performed for the $\mathrm{N}$ content of water from the two seasons, as shown in Figure 4. The results show that while during the spring there is a moderate $\mathrm{N}$ removal, in summer the water collected at the drainage ditch (output) significantly differs from that of the river and irrigation ditch in terms of nitrogen content.

\section{Discussion}

Previous investigations directed on the same experimental site (Gumiero et al., 2011; Boz et al., 2013; Rahman et al., 2014), unambiguously demonstrated that the conditions created by the specific soil management adopted on the wooded riparian strip under study, supported bacterial diversity and denitrification activity. A needed complement of the above studies was to evaluate the effect of the riparian buffer management on the composition of the bacterial population of water. Therefore, the goal of the present investigation was to understand how the bacterial community of the river changes by passing through the riparian strip soil.

The results of this study clearly indicates that the size of the bacterial population, including the culturable fraction, increases from the river to the drainage ditch especially on the warm season (July), gaining more than one order of magnitude in the output water. This is in accord with previous reports (e.g. Feng et al., 2009). The multiple approach here adopted enabled also to demonstrate that the special condition created by forcing the water flow through the buffer strip specifically designed and afforested with suitable plant species, supports the development and the metabolism of the bacterial population. As the river flux uses to collect water from a range of different sites, namely urban settlements, livestock farms and agricultural soils, the water may be enriched with undesired microbial species. This suggested investigating on the nature of the bacterial population in terms of phylotypes distribution. In effect, $16 \mathrm{~S}$ rDNA analysis indicated that the most represented genera belong to Gamma-proteobacteria lineage, which is known to include an exceeding number of important pathogens. On the other hand, in spring, the effect of the buffer strip seems to significantly (more than $30 \%$ ) reduce such a sub-population.

All the above observations indicate that although there is a clear increase in the population size, probably due to the release of bacteria from soil to water flux, the composition of the community in the output water changes, in spring, by following a desired direction. By considering the total bacterial community composition, the changes observed become more evident in the summer, as revealed by both DGGE cluster analysis, where the profiles related to the output flux resulted clearly

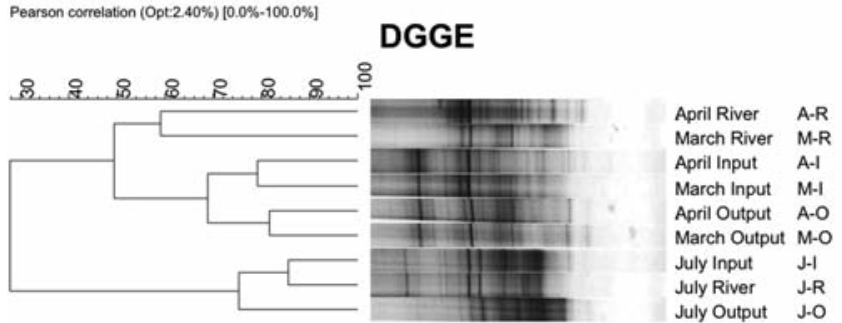

Figure 3. Comparison of the bacterial community compositions by cluster analysis of denaturing gradient gel electrophoresis (DGGE) profiles. The dissimilarity matrix for each sample was determined using Pearson correlation, and clustering was performed by BioNumerics. The highest dissimilarity value between samples was set at $100 \%$. Three different DGGE runs were carried out for all samples. Samples were collected directly from the river $(R)$, from the irrigation ditch (I) and from the output water of the drainage ditch (O) in March (M), April (A) and July (J).

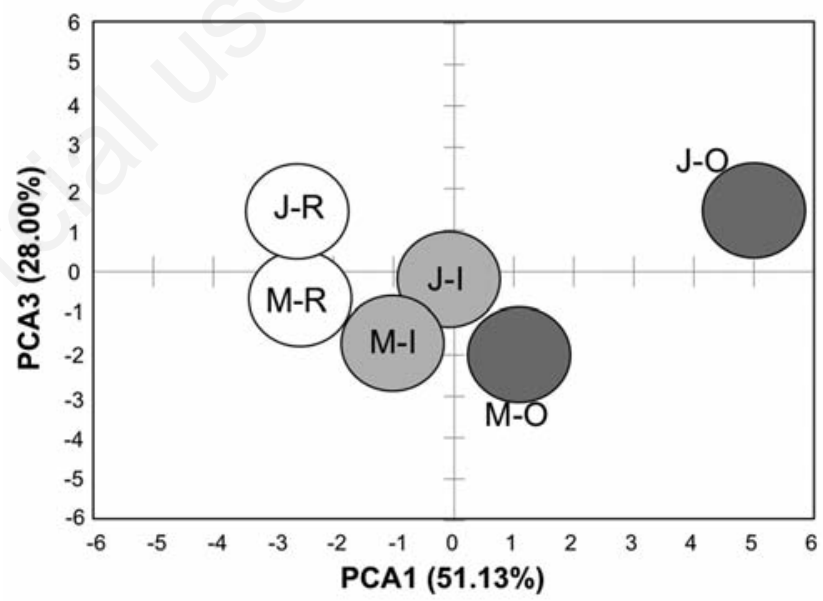

Figure 4. Principal component analysis (PCA) biplot of the total nitrogen removal from water at two seasons (M: March, J: July) and three sites (R: river, I: input, O: output).

Table 1. Shannon diversity index of bacterial communities of water at three different sites.

\begin{tabular}{lcc}
$\begin{array}{l}\text { Sampling } \\
\text { names }\end{array}$ & $\begin{array}{r}\text { Culturable bacterial } \\
\text { community }\end{array}$ & $\begin{array}{c}\text { Total bacterial } \\
\text { community }\end{array}$ \\
M-R & 1.50 & 2.15 \\
M-I & 1.35 & 1.89 \\
\hline M-O & 1.68 & 3.10 \\
J-R & 1.76 & 2.25 \\
\hline J-I & 1.81 & 2.59 \\
J-O & 1.97 & 3.45 \\
\hline
\end{tabular}

M, March; R, river water; I, input water (irrigation ditch); O, output water (drainage ditch); J, July. 
separated, and by the diversity index calculation. In conclusion, the hydraulic management coupled to the suspension of farming practices and to the development of the woody and herbaceous vegetation produce a condition suitable for the containment of undesired microbiota (mainly during the spring season) while continuing to support denitrification activity (especially throughout the summer) as verified by the total $\mathrm{N}$ removal.

\section{References}

Acinas SG, Anton J, Rodriguez-Valera F, 1999. Diversity of free-living and attached bacteria in offshore western Mediterranean waters as depicted by analysis of genes encoding 16S rRNA. Appl. Environ. Microb. 65:514-22.

Azam F, Long RA, 2001. Sea snow microcosms. Nature 414:497-8.

Basaglia M, Povolo S, Casella S, 2007. Resuscitation of viable but not culturable Sinorhizobium meliloti 41 pRP4-luc: effects of oxygen and host plant. Curr. Microbiol. 54:167-74.

Bowman JP, McCammon SA, Gibson JAE, Robertson L, Nichols PD, 2003. Prokaryotic metabolic activity and community structure in Antarctic continental shelf sediments. Appl. Environ. Microb. 69:2448-62.

Boz B, Rahman Md M, Bottegal M, Basaglia M, Squartini A, Casella S, 2013. Vegetation, soil and hydrology management influence denitrification activity and the composition of nirK-type denitrifier communities in a newly afforested riparian buffer. New Biotechnol. 30:675-84.

DeLong EF, Karl DM, 2005. Genomic perspectives in microbial oceanography. Nature 437:336-42.

Feng BW, Li1 XR, Wang JH, Hu ZY, Meng H, Xiang LY, Quan ZX, 2009. Bacterial diversity of water and sediment in the Changjiang estuary and coastal area of the East China Sea. FEMS Microbiol. Ecol. 70:236-48.

Fuhrman JA, McCallum K, Davis AA, 1993. Phylogenetic diversity of subsurface marine microbial communities from the Atlantic and Pacific Oceans. Appl. Environ. Microb. 59:1294-302.
Gumiero B, Boz B, Cornelio P, Casella S, 2011. Shallow groundwater nitrogen and denitrification in a newly afforested, sub-irrigated riparian buffer. J. Applied Ecol. 48:1135-44.

Heijs SK, Laverman AM, Forney LJ, Hardoim PR, van Elsas JD, 2008. Comparison of deep-sea sediment microbial communities in the Eastern Mediterranean. FEMS Microbiol. Ecol. 64:362-77.

Ibekwe AM, Poss JA, Grattan SR, Grieve CM, Suarez D, 2010. Bacterial diversity in cucumber (Cucumis sativus) rhizosphere in response to salinity, soil pH, and boron. Soil Biol. Biochem. 42:567-75.

Kapley A, Baere TD, Purohit HJ, 2007. Eubacterial diversity of activated biomass from a common effluent treatment plant. Res. Microbiol. 158:494-500.

Kelly KM, Chistoserdov AY, 2001. Phylogenetic analysis of the succession of bacterial communities in the Great South Bay (Long Island). FEMS Microbiol. Ecol. 35:85-95.

Knowles R, 1982. Denitrification. Microbiol. Rev. 46:43-70.

Pommier T, Canback B, Riemann L, 2007. Global patterns of diversity and community structure in marine bacterioplankton. Mol. Ecol. $16: 867-80$.

Rahman Md M, Basaglia M, Vendramin E, Boz B, Fontana F, Gumiero B, Casella S, 2014. Bacterial diversity of a wooded riparian strip soil specifically designed for enhancing denitrification process. Biol. Fertil. Soils 50:25-35.

Sala MM, Terrado R, Lovejoy C, Unrein F, Pedros-Alio C, 2008. Metabolic diversity of heterotrophic bacterioplankton over winter and spring in the coastal Arctic Ocean. Environ. Microbiol. 10:942-9.

Shannon CE, Weaver W, 1963. The mathematical theory of communication. University of Illinois Press, Urbana, IL, USA.

Toffanin A, Basaglia M, Ciardi C, Vian P, Povolo S, Casella S, 2000. Energy content decrease and viable-not-culturable status induced by oxygen limitation coupled to the presence of nitrogen oxides in Rhizobium 'hedysari'. Biol. Fert. Soils. 31:484-8.

Valderrama JC, 1981. The simultaneous analysis of total nitrogen and total phosphorous in natural waters. Marine Chem. 10:109-22.

Vieira RP, Gonzalez AM, Cardoso AM, 2008. Relationships between bacterial diversity and environmental variables in a tropical marine environment, Rio de Janeiro. Environ. Microbiol. 10:189-99.

Zehr JP, Ward BB, 2002. Nitrogen cycling in the ocean: new perspectives on processes and paradigms. Appl. Environ. Microb. 68:1015-24. 